\title{
Consistent magma conditions at Mt Pinatubo, Philippines, over 2.5 m.y.
}

\author{
W. MIDEA ${ }^{1 *}$ AND K. HATTORI $^{1}$
}

${ }^{1}$ Department of Earth and Environmental Sciences, University of Ottawa, Ottawa, Canada, K1N 6N5 (*correspondance:

wmide063@uottawa.ca).khattori@uottawa.ca

The 1991 eruption products at Mt Pinatubo, Philippines, show the magma was cool, $<800{ }^{\circ} \mathrm{C}$, and oxidized, $>\mathrm{FMQ}+2.5$. Immiscible aqueous fluids drove hydrothermal activity forming $\mathrm{Cu}$ minerals. Dacite-andesite and unmineralized diorite porphyry at the $2.5 \mathrm{Ma}$ Dizon deposit ( $0.67 \mathrm{Mt} \mathrm{Cu}, 140 \mathrm{t} \mathrm{Au}$ ) on the southern flank of Mt Pinatubo, and 5100 BP Mt Pinatubo dacite show similar mineralogy and textures to the 1991 eruption products. These older igneous rocks show abundant evidence of multiple injections of hot mafic magmas, such as destabilization of plagioclase and basalt enclaves. Fe-Ti oxide geothermobarometry and amphibole thermobarometry yield their parental magmas were hydrous $\left(5.8-7.1 \mathrm{wt} \% \mathrm{H}_{2} \mathrm{O}\right)$ and oxidized $(\mathrm{FMQ}+1.8$ to +3.3$)$. The dacite parental magmas were cool, $\sim 820^{\circ} \mathrm{C}$ and shallow, at a depth of $\sim 3 \mathrm{~km}$. The temperature estimate is consistent with cummingtonite rims of $\mathrm{Hbl}$. The diorite amphibole yields elevated temperatures $\sim 980^{\circ} \mathrm{C}$, and greater depths of $\sim 15 \mathrm{~km}$. The magma conditions are very similar to those for the 1991 eruption product. The results suggest that the magma conditions were similar for at least $2.5 \mathrm{~m} . \mathrm{y}$. throughout the development of Mount Pinatubo.

Furthermore, the oxidation conditions and temperatures for the magmas at Pinatubo are similar to those responsible for large porphyry $\mathrm{Cu}$ deposits elsewhere including the Bingham Canyon, El Salvador and Yerington deposits. 